(C) 2019. This manuscript version is made available under the CC-BY-NC-ND 4.0 license http://creativecommons.org/licenses/ by-nc-nd/4.0/

\title{
Valuation of subsoil minerals in Bangladesh: An application of the system of environmental-economic accounting
}

\begin{abstract}
This study applies an alternative accounting framework that is the System of EnvironmentalEconomic Accounting (SEEA) to undertake a valuation of the two most important sub-soil minerals, namely natural gas and coal, in Bangladesh. This framework outlines the method of preparing physical and monetary balance sheets of these two sub-soil minerals. Our empirical results show that the physical stock of natural gas has been diminishing rapidly because of its present excessive consumption in many sectors. The annual reduction of stock ranged from 6.94 to 7.56 per cent of the monetary value of the stock between 2011-12 and 2016-17 with fluctuations over time. However, the depletion rate of the stock of coal is much lower and ranges around 0.023 to 0.056 per cent of the monetary value of the stock. Furthermore, the value of the stock of both the minerals has been found to be highly sensitive to the choice of discount rate; for a lower discount rate the value of stock is higher, and vice versa.
\end{abstract}

Key words: Subsoil resources; SEEA; Net present value; Resource rent; Physical balance; Monetary balance

JEL Classification: Q32, Q56, Q24 


\section{Valuation of subsoil minerals in Bangladesh: Application of the system of environmental-economic accounting}

\section{Introduction}

The conventional System of National Accounts (SNA) is frequently criticized for the inability of the Gross Domestic Product (GDP) to be a satisfactory measure of welfare derived from the utility of the standard value of output (Howarth and Farber, 2002). Its inadequacy is further compounded in the case of developing countries where the quality of the GDP is equally important because of the aggressive rate of extraction of subsoil mineral resources like natural gas and coal from the geo-sphere to accommodate production processes. However, national accounting measures of many developing countries tend to exclude the environment, which makes it impossible to comprehend or to adequately quantify the impact of rapid natural resource depletion on the environment and the economy. Hence, devising more durable environmental policies which do not compromise ongoing economic expansion in developing and emerging economies is of paramount importance. For this reason, green national accounting has attracted significant attention in the literature, particularly over the last three decades, and in the last twenty years there has been considerable debate over the accounting method to be used (Dasgupta, 2013). In recent years, green measures of income and other related indices have started to play an important role in providing comprehensive economic information systems. Such recognition of the importance of green national accounting is consistent with the standard view of national accounting systems, such as the SNA (Heal and Kriström, 2005).

Understanding the welfare of national income was the initial point of departure for green accounting while also serving as one of the foundations of green accounting and durable environmental regulation. In a seminal contribution, Weitzman (1976) showed the significance of analyzing the dynamic welfare of comprehensive national accounting aggregates and the uses to which they can be put to determine differences in the welfare of populations and for assessing whether development is sustainable. Weitzman's contribution led to subsequent contributions on welfare and sustainability accounting (Hartwick, 1990; Mäler, 1991) to explicitly include natural resources and the environment in national accounting. They proposed corrections to national accounting to include the degradation of the wealth of natural resources and the value of the environment. 
Harnessing natural resources, especially extractive ones (i.e. natural gas, oil and soil minerals such as coal and hard rock), is important for sustainable development. But setting the extraction rate of natural resources in a sustainable and integrated manner is also essential for sustainable development. Sustainable development is conceived as a development trajectory which does not maximize the well-being of today's generations at the expense of the well-being of generations to come (Lawn, 2003). Hence, understanding the stock value of exhaustible natural resources is crucial to reversing their rapid depletion.

Being one of the most densely populated countries in the world, Bangladesh has been prevented, because of economic imperatives, from adopting a growth and development path that takes into account the adverse impacts of mineral depletion and environmental degradation. However, an initiative is currently underway to estimate the value of the natural resource stock in the country so as to arrive at an optimal rate of extraction that is commensurate with the stipulated path of national economic growth and development. ${ }^{1}$ At present, the contribution of natural resources such as minerals, water, fishery and forestry is calculated for financial years using the value added method of national income accounting following the SNA 2008 (United Nations et al., 2008). It is important, therefore, to conduct a comprehensive accounting of national wealth to serve as the basis of natural resource planning for the country.

Given this backdrop, the present study applies the System of Environmental-Economic Accounting (SEEA) to undertake a valuation of the two most important sub-soil minerals, i.e. natural gas and coal, in Bangladesh. A study in this way has not been undertaken before. ${ }^{2}$ The subsoil minerals constitute a case study to test the usefulness of the SEEA to Bangladesh. The study has two objectives: firstly, to demonstrate how to conduct valuation of subsoil minerals as a part of the SEEA for Bangladesh and to contribute to the literature on the SEEA for green national accounting. With these objectives in mind, we have organized the rest of the paper as follows.

\footnotetext{
${ }^{1}$ Bangladesh Bureau of Statistics (BBS) has developed the Bangladesh Framework for Development of Environment Statistics 2017 in which a component deals with "Environmental Resources and Their Use". It is in the process of undertaking valuation of natural resource stock of the country.

2 The first comprehensive operational framework of environmental accounting, called the System for Integrated Environmental and Economic Accounting (SIEEA), was proposed by the United Nations Statistical Division (1993), but as the outline of a satellite account to the SNA for environmental goods and natural resources. Subsequently, the SEEA Central Framework (2014), which set out in detail the accounting structure that has been adopted as an international standard by the United Nations Statistical Commission (UNSC). It is also regarded as the first international statistical standard for environmental-economic accounting and contains a multipurpose conceptual framework for comprehending the interactions between the economy and the environment, and for recounting stocks and changes in stocks of environmental assets.
} 
Section 2 presents a brief account of the major subsoil minerals of the country. Section 3 gives the methodology for conducting the valuation of natural gas and coal using the SEEA framework. Section 4 provides the results and analysis of empirical findings. Section 5 raises some critical issues about the SEEA relating to the valuation of sub-soil minerals and their implications for national accounting. Section 6 offers some concluding remarks and policy implications.

\section{Subsoil Minerals of Bangladesh: An Overview}

Bangladesh's major mineral resources are natural gas, coal, peat, hard rock and gravel. Of these, natural gas is the major mineral and energy resource of the country. It is used mostly in producing electricity, fertilizer, fuel for motor vehicles, energy, and inputs for households and industries (Figure 1a). An estimate of the state-run Oil, Gas and Mineral Resources Corporation (known as Petrobangla) suggested the proven gas reserve of Bangladesh was 13.6 trillion cubic feet (TCF) (Petrobangla, 2018a). The state-run Oil, Gas and Mineral Resources Corporation (Petrobangla) supplied about 2.65 billion cubic feet (BCF) of gas per day or about 0.969 TCF in 2016-17. Even though the demand for natural gas has been expanding rapidly in manufacturing, power generation, transport and households, no significant discoveries in natural gas have been made in recent years. In fact, Sangu, a prominent offshore gas field, was shut down permanently in October 2013 as a response to the rapid decline in reserves beyond a critical level that has raised a debate about overextraction that led to the alleged 'premature death' of a dependable source of natural gas serving the commercial capital of the country. The rapid depletion in gas reserves is likely to have a detrimental impact on the entire economy in the foreseeable future.

\section{Figure 1a: Use of Natural Gas by Sector (2016-17)}

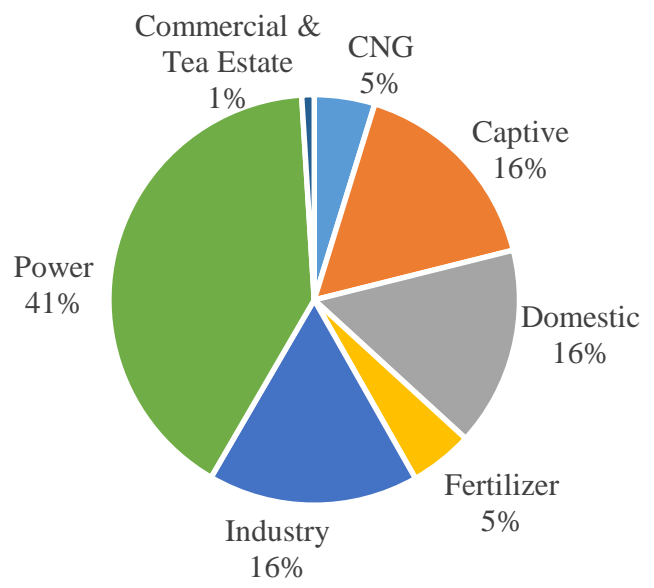

Source: Based on Petrobangla MES Report, July 2017 
Figure 1b: Use of Domestic Coal by Sector (\%)

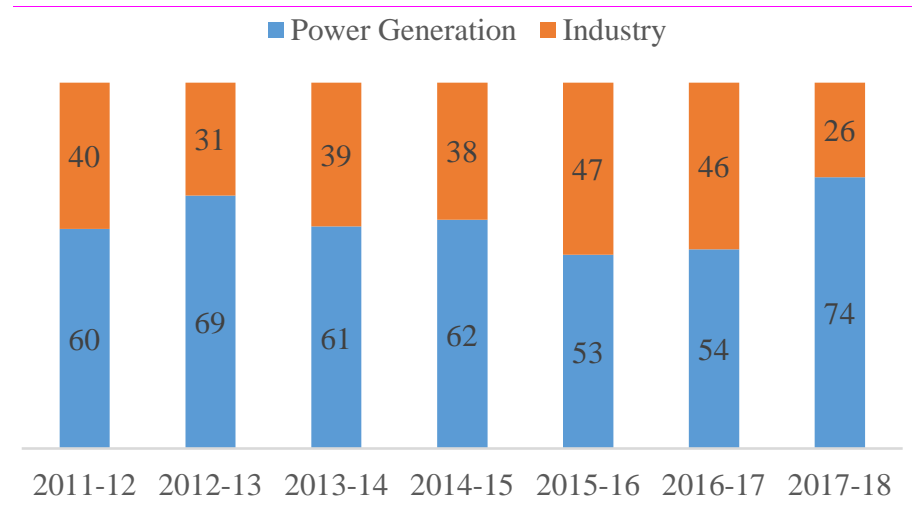

Source: Based on Sales statistics of Barapukuria Coal Mining Company Ltd, available at https://bcmcl.org.bd/salesstatistics/, accessed on 09 January 2019.

In addition to gas, coal is an important energy input and domestically extracted coal is in use in many areas. Domestically produced coal is used in power generation and by local industries (Figure 1b). The estimated reserve of coal is 1.66 billion tons in four coal mines. Extraction is taking place in the Barapukuria coal mine, which is the second largest reserve of the country (at 300 million tons). A large reserve of hard rock is located at Maddhapara. Hard rock deposits have also been recorded at Ranipukur, Pirganj Bogra, Jamalganj, and Kansat (Rahman, 1997). In addition to these, there are surface deposits of construction materials such as boulders and gravel. (See Appendix Maps). ${ }^{3}$

Figure 2: Production of Coal ('000' Short Ton)

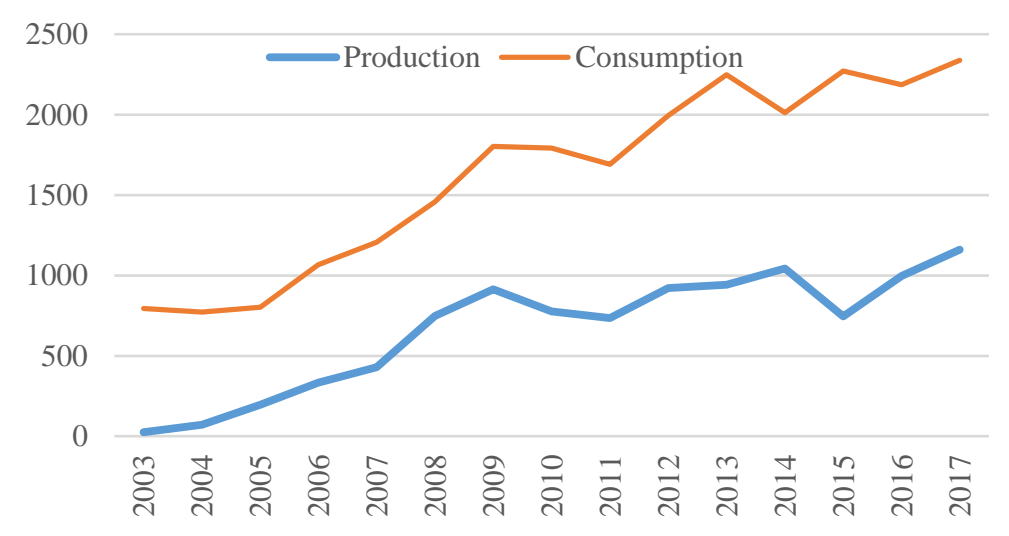

Data source: Based on US Energy Information Administration, BP Statistical Review and Petrobangla Annual Report (2018b).

\footnotetext{
${ }^{3}$ The hard rocks of Bangladesh are classified as (i) Maddhyapara subsurface hard rock, (ii) Bholaganj-Jaflong hard rock concretions, (iii) Tetulia-Patgram-Panchagarh hard rock concretions, and (iv) Chittagong-Chittagong Hill Tracts sedimentary concretions.
} 
Coal is gradually becoming an important source of energy in Bangladesh. Five coal mines have an estimated reserve of more than 3 billion tons (Petrobangla, 2018). Since its first production of a mere 25,000 short ton in 2003, the domestic production of coal has reached 1.16 million ton in 2017 with an increasing trend (Figure 2). Barapukuria coal power plant is a 525-megawatt power station, which requires 0.6 million ton coal annually from Barapukuria mine. Three other major coal-fired power plants are going to be established in the near future and these will use imported coal. These are the proposed Rampal power plant adjacent to Sundarbans with 1320-megawatt capacity, Matarbari power station with 1200-megawatt capacity, and Payra power station with 1200-megawatt capacity. Among them, Rampal power plant has created considerable public controversy because of its assumed negative environmental effects on its surroundings including river ecosystems and Sundarbans area.

Even though it started with underground mining, Barapukuria Coal Mining Company has been adopting open-pit mining methods since 2016 to extract coal from the only active coal mine. This method would also be adopted in Phulbari mine. However, there has been considerable debate in the public sphere for some time on the open-pit mining method of extraction of coal because of its adverse impacts on the environment and livelihoods. For example, the local inhabitants have experienced damages to their houses and dried up water bodies adjacent to the Barapukuria coal mine. ${ }^{4}$ In addition, the role played by International Oil Companies (IOCs) in the energy sector have been found to play quite aggressive roles in extracting natural gas as is evident from the increase in their share of total gas production which has grown to 60 percent in 2016-17 from 52 percent in 2010-11. Since the country is critically dependent on minerals like natural gas and coal for nearly all sectors of the economy including manufacturing and services, it is important to arrive at a proper valuation of these resources to generate useful information for the government to determine an optimal extraction policy.

\section{Methodology and Data}

The System of National Accounts (SNA) 2008 describes the method of calculating the present value of future returns from the stock of subsoil assets. It suggests using a rate of discount to calculate the present value of the expected future returns in addition to the valuation of annual

\footnotetext{
${ }^{4}$ See, "Barapukuria Coal Mine: Cracks in houses in surrounding areas, lakes drying up". Available at https://bdnews24.com/bangladesh/2016/11/26/barapukuria-coal-mine-cracks-in-houses-in-surrounding-areas-lakesdrying-up, retrieved on 30 December 2018.
} 
output using market prices (p. 265). It also tries to assign a capital value of subsoil minerals (since these are rarely sold on the market) by assessing the economic rent to be earned by the stock of minerals. For the stock of natural gas and coal, which have no natural capacity to be renewed, the SNA 2008 suggests that their contribution to production (output) should be decomposed into decline in value of the deposit and a residual element. In doing so, it suggests green accounting, which allows for "consumption of natural capital as well as consumption of fixed capital in an alternative presentation of national accounts in a satellite account" (p. 421). It is because the valuation of annual output can be done using the standard SNA, but it does not capture the expected future value of the mineral deposit or the residual element.

\subsection{Accounting method in SEEA}

The SEEA Experimental Ecosystem Accounting (2013) provides a common set of terms, concepts, accounting principles and classifications, an integrated accounting structure of ecosystem services and conditions in both physical and monetary terms, and the recognition of spatial areas as forming the basic focus for measuring various ecosystem and asset accounting including carbon. ${ }^{5}$ Physical flow accounts provide systematic physical descriptions of physical flow including the extraction of natural resources, their use and transformation within the economy, and the return to the environment. Conversely, monetary accounts identify environmentrelated transactions in the existing SNA flow accounts to make them more explicit for analysis. Another account called the asset account takes into account the stocks and changes in stocks (flows) of gas and coal resources in physical and monetary terms. Wealth accounts and depletion are also calculated in this account. Finally, the SEEA Central Framework (United Nations et al., 2014a) provides a combined module to form a full sequence of national accounts. It also integrates the physical and monetary accounts to obtain the relevant aggregates. The SEEA Experimental Ecosystem Accounting provides accounting for ecosystem stocks, the capacity of ecosystems to provide services, degradation in natural resource stocks and, finally, carbon and biodiversity accounts (United Nations et al., 2014b).

Following the SEEA Central Framework (2014), physical and monetary balance sheets can be prepared separately for natural gas and coal. The physical balance sheets consist of several

\footnotetext{
${ }^{5}$ However, Dasgupta et al. (2013) claim that the classification scheme described in the SEEA suffers from serious shortcomings. They suggest a number of measures for making the SEEA more conveniently serve the purposes of economic evaluation of environmental accounts. The SEEA also does not attempt to measure welfare; rather it works out the output in environmental accounts.
} 
items. Each accounting year starts with an opening stock which is equal to the closing stock of the previous year. During the year, the opening stock is altered by three annual flows: reappraisal of existing reserves, new discoveries, and extractions. The combination of these items results in a physical balance sheet for natural gas and coal.

To prepare the monetary balance sheets for gas and coal reserves, an appropriate valuation method is followed and assumptions are made on future physical extractions, the resource rent and the discount rate. The value of an asset in the national accounts should reflect the value of the asset were it to be traded in an open market. Nordhaus (2000) has discussed different methods of mineral valuation, such as the current rent method that describes variants of the Net Present Value (NPV) method such as the two types of current rent method based on the Hotelling valuation principle. ${ }^{6}$ It also calculates the value of minerals by using these methods to provide a comparative picture of valuation for the USA. It uses two different discount rates for assessing the sensitivity of findings. Cairns and Davis (1998) have provided an algebraic representation of the NPV, which is an improvement over Nordhaus (2000) as it takes the Risk-Adjusted Discount Rate (RADR) instead of the simple discounting used in the NPV method, thus implying that higher discount rates could result in lower asset values and vice versa. Veldhuizen et al. (2009) have laid out a detailed framework of valuation of oil and gas reserves in the Netherlands within an SEEA-consistent framework. It uses the NPV method for the valuation of these mineral resources for 1990-2005 based on scenarios of physical extraction and expected resource rent. The SEEA Central Framework (2014) also suggests the use of the NPV for the valuation of subsoil minerals. However, the methodology of valuation in SEEA (2014) is different from that of Veldhuizen et al. (2009).

In Bangladesh, the marketing of natural gas is a state monopoly while the extraction of coal domestically is undertaken by the Barapukuria Coal Mine Company, which is also state-owned. Bangladesh also imports large volumes of coal from India, at what can be considered a market price. However, since the observed market values for transactions in oil and gas reserves are not widely available, we use the NPV method to give a monetary value to the physical stocks of reserves. This method is recommended in the Handbook on Measuring Capital (OECD) and in the SEEA Central Framework (2014).

\footnotetext{
${ }^{6}$ Hotelling, H. (1931), 'The Economics of Exhaustible Resources', Journal of Political Economy 39(2):137-175.
} 


\subsection{Value of stock at period $t^{7}$}

Following the SEEA Central Framework (2014), the valuation of stock of natural gas and coal can be described as follows. Assuming all yearly income from the extraction of reserves is received at the end of the year, the NPV of future income from the reserves at the beginning of year $t$ can be written as:

$$
V_{t}=\sum_{t=1}^{N_{t}} \frac{R R_{t+\tau}}{\left(1+r_{t}\right)^{\tau}}
$$

where $r_{t}$ is a nominal discount rate valid at time $t, R R_{t}$ is the resource rent at $t, \tau=1,2, \ldots, N_{t}$; and $V_{t}$ is the value of the stock at the end of period $t$. Thus, $R R_{t+\tau}$ is the nominal value of expected future resource rents while the projected time profile of the resource rent $\left\{R R_{t+1}, R R_{t+2}, \ldots\right\}$ may be non-constant. ${ }^{8}$

The resource rent $\left(R R_{t}\right)$ is the net income from extraction defined as the total revenue from sales less all costs incurred in the extraction process including the user cost of produced capital. ${ }^{9}$ The $R R$ is composed of two components, quantity of the resource extracted $\left(S_{t}\right)$ and price per unit of the resource extracted $\left(P_{S t}\right)$. The second component is equivalent to the unit resource rent, i.e., the rent per extracted unit of resource. Here, $R R_{t}$ has been assumed to be observable from the rent payments that extraction enterprises pay to the owner of a natural resource. In the present analysis, the owner of the resource is the Government of Bangladesh.

Here, $V_{t}$ is composed of a price $\left(P_{t}\right)$ and a quantity of (a single resource) $\left(X_{t}\right)$ components. In the present case, if $V_{t}$ is the value of natural gas, $P_{t}$ equals the price per cubic feet of natural gas at the end of period $t$, and $X_{t}$ is the number of cubic feet of gas at the end of period $t$, we therefore have

$$
V_{t}=P_{t} X_{t}
$$

To obtain an estimate of the price $P_{t}$ and subsequently of $V_{t}$, we use the NPV condition from equation (1) together with the definition of the resource rent $R R_{t}=P_{S t} S_{t}$ :

\footnotetext{
${ }^{7}$ Sub-sections 3.2 and 3.3 are based on the SEEA Central Framework (2014). However, the traditional SNA does not provide separate formulations of subsoil mineral accounting other than market price of annual output, and including cost of exploration and evaluation of minerals in the company's gross fixed capital formation.

${ }^{8}$ This is a three-year moving average to estimate the expected unit resource rent.

${ }^{9}$ It is also equivalent to the total value of the natural resource input into the production process in an accounting period.
} 


$$
V_{t}=P_{t} X_{t}=\sum_{t=1}^{N_{t}} \frac{P_{S, t+\tau} S_{t+\tau}}{\left(1+r_{t}\right)^{\tau}}
$$

The SEEA Central Framework suggests making two alternative assumptions about the future rate of extraction of non-renewable natural resources and the expected price change of $P_{S t}$. One is that the most recent size of extraction will prevail in future extractions so that $S_{t+\tau}=S_{t}(\tau=$ $\left.1,2,3, \ldots, N_{t}\right)$. To avoid the effect of unusually large or small extractions in a particular year, the rate of extraction can be excluded, and a moving average can be taken from the rate of extraction of the most recent three years by assuming that such unusual rates of extraction are unlikely to occur again in the future. Another assumption is for a constant rate of extraction, so that $S_{t+\tau} / X_{t+\tau}$ is constant for $\tau=1,2,3, \ldots, N_{t}$. However, in this present study, we decided to adopt the first assumption to accommodate the usual changes in extraction over time.

\subsection{Depletion, discoveries and losses}

In the ex post sense, the difference between $X_{t}$ and $X_{t-1}$ can be decomposed into three components: depletion (or extraction), discoveries and other additions, and catastrophic losses and other reductions. However, ex ante, discoveries and catastrophic losses are unknown at the end of the

preceding period $t-1$. Hence, depletion is defined as $S_{t}=X_{t-1}^{\prime}-X_{t}^{\prime}$ where $S_{t}$ is the extraction during period $t$, and $X_{t}^{\prime}$ is the quantity of subsoil minerals at the end of $t$ given the information available at the end of $t-1$. Discoveries constitute an unexpected addition to the resources while catastrophic losses indicate their unexpected and significant reductions during the accounting period. Their combined effect can be measured as $X_{t}-X_{t}^{\prime}$ or the difference between actual and expected quantities at the end of the period. In order to disentangle the discoveries and catastrophic losses, let $I_{t}$ and $L_{t}$ be the physical amount of discoveries and catastrophic losses, respectively, such that $X_{t}-X_{t}^{\prime}=I_{t}-L_{t}$. Thus, the total physical changes in the resources between the beginning and the end of the accounting period are:

$$
\left(X_{t}-X_{t-1}\right)=\left(X_{t}-X_{t-1}^{\prime}\right) \equiv \triangle X_{t}=\left(X_{t}-X_{t}^{\prime}+X_{t}^{\prime}-X_{t-1}^{\prime}\right)=I_{t}-L_{t}-S_{t}
$$

The change of value of a resource between $t$ and $t-1$ given the available information in both the periods can now be decomposed as 


$$
\left(V_{t}-V_{t-1}\right)=\left(V_{t}-V_{t-1}^{\prime}\right)=\left(P_{t} X_{t}-P_{t-1} X_{t-1}\right)=\underbrace{P_{t-1} \Delta X_{t}}_{\begin{array}{l}
\text { Quantity } \\
\text { Effect }
\end{array}}+\underbrace{X_{t} \Delta P_{t}}_{\begin{array}{l}
\text { Revaluation } \\
\text { Effect }
\end{array}}
$$

Alternatively, the two effects can be expressed as follows:

$$
\left(V_{t}-V_{t-1}\right)=\underbrace{0.5\left(P_{t-1}+P_{t}\right) I_{t}}_{\text {Discoveries }}-\underbrace{0.5\left(P_{t-1}+P_{t}\right) L_{t}}_{\text {Catastrophic Losses }}-\underbrace{0.5\left(P_{t-1}+P_{t}\right) S_{t}}_{\text {Depletion }}+\underbrace{0.5\left(X_{t-1}+X_{t}\right) \Delta P_{t}}_{\text {Revaluation }}
$$

The valuation of depletion with the average price of the period is consistent with the SNA for valuation of consumption of fixed capital. Also, discoveries and catastrophic losses are valued with mid-period prices to remain consistent with the valuation of depletion. The depletion-adjusted resource rent can be written as

$R R_{t}^{\prime}=r_{t} V_{t-1}^{\prime}-0.5\left(X_{t-1}^{\prime}+X_{t}^{\prime}\right) \triangle P_{t}^{\prime}+0.5\left(P_{t-1}^{\prime}+P_{t}^{\prime}\right)\left(S_{t}-G_{t}\right)$

\subsection{Data sources}

The study is mainly based on data available from Petrobangla and the Ministry of Power, Energy and Mineral Resources of the Government of Bangladesh. In Bangladesh, the tariff (user price) of minerals is determined by the Bangladesh Energy Regulatory Commission (BERC). The last tariff revision was done in September 2011 although only for Compressed Natural Gas (CNG). Thus, there has been no change in the price of gas and related petroleum (generated as by-products) for the accounting period of monetary balance. ${ }^{10}$ The data of price and user cost of capital have been taken from Petrobangla MES and annual reports.

We calculated the rate of extraction from a three-year moving average rather than a constant rate of extraction in physical terms taking into account the non-food inflation ${ }^{11}$ for incorporating the price level fluctuations. We adjusted the resource rent for price level fluctuations

\footnotetext{
10 The method described above can be used when prices and resource rents do not experience substantial fluctuations. Since we found a large fluctuation in unit resource rent with negative resource rent in the last (2013-14) fiscal year, we follow$$
\mathrm{NPV}_{t}=R R_{t} \sum_{t=0}^{N_{t}} \frac{(1+\rho)^{\tau}}{(1+r)^{\tau}}=R R_{t} \Omega
$$

where $\rho=$ rate of inflation of non-food items.

${ }^{11}$ Bangladesh Bank (2018), Economic Trends: January 2018, Bangladesh Bank, Dhaka.
} 
while also addressing the unusual large number or small number possibility in resource rent. As mentioned above, the valuation of reserve and flow has been carried out through the creation of physical and monetary balance sheets. We derive the data for compiling the physical balance sheets for natural gas and coal from what is available at Petrobangla (up to June 2017) and from various reports of the Bangladesh Bureau of Statistics including the database of the Statistical Yearbook (2011 to 2016). The volumes in the physical balance sheets have been presented in terms of 'cubic meters' and 'tons', respectively. The physical balance sheets consist of three elements, namely, the physical opening stocks, the different sources of annual alteration to physical stocks, and the resulting closing stocks of physical reserves.

\section{Analysis of empirical results}

\subsection{Physical Balance}

The gas reserve in Bangladesh, given in Petrobangla's reserve data, the annual reports and the monthly MES reports, is usually reported on the $2 \mathrm{P}$ basis, i.e., proven and probable reserve. While roughly half of the reserve of natural gas is proven, the literature suggests the estimated probable reserve is also quite reliable. However, as per Petrobangla's official data, the reserve of natural gas has experienced a significant upward movement in 2011 because of reappraisal of reserves (see Table 1).

\section{Table 1: Natural Gas Reserve (TCF)}

\begin{tabular}{cccc}
\hline \hline Year & $\begin{array}{c}\text { Gas Initial } \\
\text { In Place } \\
\text { (GIIP) }\end{array}$ & $\begin{array}{c}\text { Recoverable } \\
\text { (proved + probable) }\end{array}$ & $\begin{array}{c}\text { Net Remaining Reserve } \\
\text { (proven + probable, 2P) }\end{array}$ \\
\hline 30 June 2010 & 28.86 & 20.61 & 12.51 \\
31 Dec 2011 & 37.62 & 26.84 & 16.74 \\
31 Dec 2012 & 37.92 & 27.04 & 16.12 \\
30 June 2014 & 37.91 & 27.07 & 14.94 \\
1 January 2016 & 38.95 & 27.12 & 13.60 \\
\hline \hline
\end{tabular}

Source: Petrobangla MES Reports and Annual Reports (various issues).

Figure 3: Demand for Natural Gas in Bangladesh 


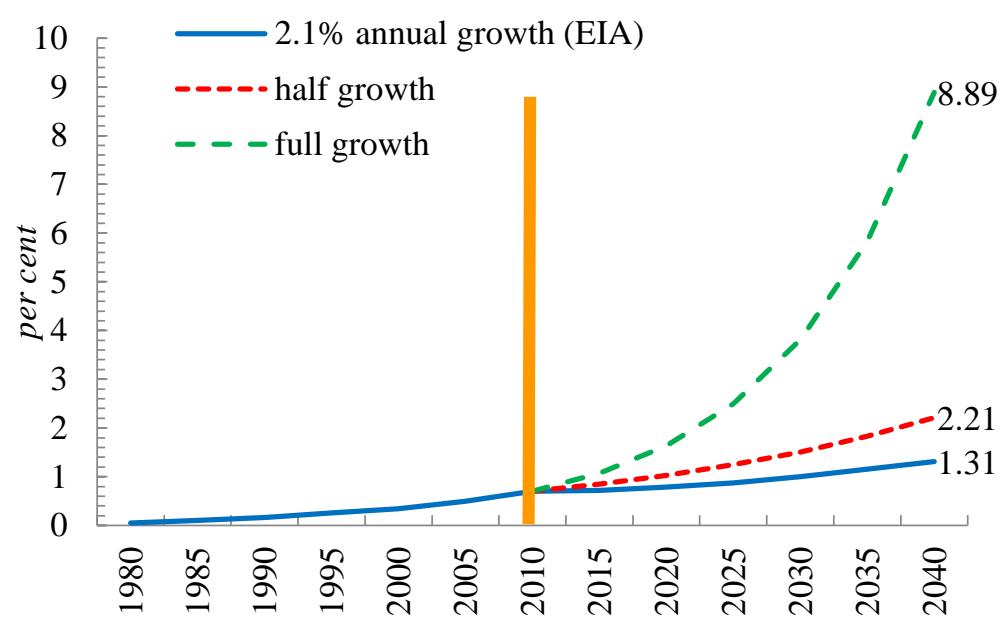

Key: Half-growth $=$ half of the growth rate of the last 10 years; Full-growth = growth rate of the last 10 years. Source: Calculation is based on US Energy Information Administration database (2017).

Rapid depletion of stocks as a consequence of high and rising domestic demand is evident from the latest figure for the net remaining reserve (Figure 3). From the 709 billion cubic feet (BCF) for the fiscal (accounting) year 2010-11, annual consumption would reach 972 BCF by the end of the fiscal year 2017-18. It reveals that at the rate of consumption for the last fiscal year available, the net remaining reserve would meet the requirements of the country for nearly 14 years. However, as consumption is bound to grow in response to increased domestic demand, there is bound to be a more rapid depletion of gas than before. In addition, many fields are bound to be declared marginal and/or abandoned even though gas would be statistically available.

The physical balance sheet for natural gas has been prepared following the SEEA Central Framework (2014) and is presented in Table 2. It reveals that a significant positive gross reappraisal of 5.57 TCF took place in the fiscal year 2010-11, which was followed by a small discovery in the next few years although there were continuous other readjustments every year.

Table 2: Physical Balance of Natural Gas (BCF)

\begin{tabular}{llccccccc}
\hline \hline S1 & Resource Stock & $\mathbf{2 0 1 0 - 1 1}$ & $\mathbf{2 0 1 1 - 1 2}$ & $\mathbf{2 0 1 2 - 1 3}$ & $\mathbf{2 0 1 3 - 1 4}$ & $\mathbf{2 0 1 4 - 1 5}$ & $\mathbf{2 0 1 5 - 1 6}$ & $\mathbf{2 0 1 6 - 1 7}$ \\
\hline $\mathbf{1}$ & Opening stock & $\mathbf{1 2 , 5 0 7}$ & $\mathbf{1 7 , 1 0 1}$ & $\mathbf{1 6 , 5 2 4}$ & $\mathbf{1 5 , 7 9 1}$ & $\mathbf{1 4 , 9 3 7}$ & $\mathbf{1 4 , 0 9 0}$ & $\mathbf{1 3 , 3 6 1}$ \\
$\mathbf{2}$ & & & & & & & \\
& $\begin{array}{l}\text { Additions to stock } \\
\text { Discoveries }\end{array}$ & 35 & 161 & 34 & & & \\
& $\begin{array}{l}\text { Upward reappraisals } \\
\text { Reclassifications }\end{array}$ & 6,274 & 213 & & & 45 & 244 & \\
& $\begin{array}{l}\text { Total additions to stock } \\
\mathbf{3}\end{array}$ & $\mathbf{6 , 2 7 4}$ & $\mathbf{2 4 8}$ & $\mathbf{1 6 1}$ & $\mathbf{3 4}$ & $\mathbf{4 5}$ & $\mathbf{2 4 4}$ & $\mathbf{0}$ \\
$\begin{array}{l}\text { Reductions in stock } \\
\text { Extractions }\end{array}$ & 709 & 744 & 801 & 820 & 892 & 973 & 969 \\
& $\begin{array}{l}\text { Catastrophic losses } \\
\text { Downward reappraisals }\end{array}$ & & & & & & &
\end{tabular}




\begin{tabular}{|c|c|c|c|c|c|c|c|c|}
\hline & Reclassifications & 971 & 82 & 93 & 67 & & & \\
\hline & Total reductions in stock & 1,680 & 826 & 894 & 887 & 892 & 973 & 969 \\
\hline 4 & Revaluations & & & & & & & \\
\hline \multirow[t]{2}{*}{5} & Closing stock & 17,101 & 16,524 & 15,791 & 14,937 & 14,090 & 13,361 & 12,392 \\
\hline & SNA & 709 & 744 & 801 & 820 & 892 & 973 & 969 \\
\hline
\end{tabular}

Source: Calculation based on Petrobangla data.

The reserve of coal shows a slowly declining trend (Table 3), which is because of small annual extractions from the Barapukuria coal field - the second largest coal mine from which the state-owned company is extracting coal. However, the demand for coal is substantial although domestic consumption has been at the same level for quite some time using imports of coal from India. Thus, from the 0.73 million ton of $2009-10$, annual extraction has risen to 1.02 billion ton in 2015-16, which implies that the remaining reserve can meet the coal demand in Bangladesh for many years to come. But the extractable stock would also depend on the extraction method used in the Phulbari coal mine, which is yet to be determined.

Table 3: Physical Balance of Coal (Million Ton)

\begin{tabular}{|c|c|c|c|c|c|c|c|c|}
\hline $\mathrm{Sl}$ & Resource Stock & 2010-11 & 2011-12 & 2012-13 & 2013-14 & 2014-15 & 2015-16 & 2016-17 \\
\hline 1 & Opening stock & 3,295 & $3,3,294$ & $3, \mathbf{3 , 2 9 3}$ & $3,3,292$ & $3,3,292$ & 3,291 & 3,290 \\
\hline 2 & $\begin{array}{l}\text { Additions to stock } \\
\text { Discoveries } \\
\text { Upward reappraisals } \\
\text { Reclassifications } \\
\text { Total additions to stock }\end{array}$ & & & & & & & \\
\hline 3 & $\begin{array}{l}\text { Reductions in stock } \\
\text { Extractions } \\
\text { Catastrophic losses } \\
\text { Downward reappraisals } \\
\text { Reclassifications }\end{array}$ & 0.7 & 0.85 & 0.89 & 0.94 & 1.04 & 1.03 & 1.02 \\
\hline 4 & $\begin{array}{l}\text { Total reductions in stock } \\
\text { Revaluations }\end{array}$ & 0.7 & 0.85 & 0.89 & 0.94 & 1.04 & 1.03 & 1.02 \\
\hline 5 & $\begin{array}{l}\text { Closing stock } \\
\text { SNA }\end{array}$ & $\begin{array}{c}3,294 \\
0.7\end{array}$ & $\begin{array}{c}3,293 \\
0.85\end{array}$ & $\begin{array}{c}\mathbf{3 , 2 9 2} \\
0.89 \\
\end{array}$ & $\begin{array}{c}\mathbf{3 , 2 9 1} \\
0.94\end{array}$ & $\begin{array}{r}3,291 \\
1.04\end{array}$ & $\begin{array}{r}3,290 \\
1.03 \\
\end{array}$ & $\begin{array}{c}3,289 \\
1.02\end{array}$ \\
\hline
\end{tabular}

Source: Calculation based on Petrobangla data.

Unlike natural gas, the physical balance of coal is composed of the opening stock and the amount extracted. In the accounting years, there has been no discovery or reappraisal reported in the Petrobangla reports. However, with regards to the monetary balance, there have been big revaluations during the fiscal year 2011-12 and revaluations have been repeated in subsequent years. Therefore, the value of stock experienced a rapid rise in 2012-13 while the stock value continued to demonstrate an upward trend in the following year following further upward revaluations. 


\subsection{Monetary Balance}

Following the SEEA Central Framework (United Nations et al., 2014), we conducted a valuation of the subsoil minerals using the residual valuation and appropriation methods. In the residual valuation method, estimates of the value of minerals are obtained using the following steps. Firstly, from relevant sources we obtained estimates of the Gross Operating Surplus (GOS) ${ }^{12}$, specific subsidies and taxes on extraction, and the user cost of produced assets for the extractive activity. Relevant activity-specific information and assumptions regarding the rate of discount of natural gas and related petroleum were derived from the national accounts data of the Bangladesh Bureau of Statistics (BBS) and Petrobangla. Secondly, we estimated the resource rent as GOS less specific subsidies plus specific taxes less user costs of produced assets. Thirdly, we estimated the asset life based on physical assessment of the stock and projected rates of extraction and growth. Finally, we projected the estimate of resource rent over the life of the asset, taking into account any expected changes in the extraction pattern.

In the appropriation method, we estimated the resource rent using the actual payments made to owners of subsoil minerals. In Bangladesh, the government is the legal owner of these resources. As legal owner, a government can collect the entire resource rent derived from the extraction of the resources that it owns. This amount would, in principle, be equal to the GOS less the user costs of the produced assets of the extractor as defined. The collection of the resource rent is generally undertaken by governments through mechanisms such as fees, taxes and royalties.

While the preparation of the physical balance sheet is quite straightforward, elements of the monetary balance sheet require inclusion under the NPV method. First is to get the data on resource rent, which is the net income from the extraction of natural gas and coal defined as total revenue from sales less all costs incurred in the extraction process including the user cost of produced capital. The data on both the revenue and costs are available in the MES reports, from which the resource rents have been calculated for each of the natural gas and coal fields (Table 4).

Table 4: Resource Rent of Minerals (Million USD)

\begin{tabular}{lclrrr}
\hline \hline Resource & Sl. & Gas/Coal Fields & 2010-11 & 2013-14 & 2016-17 \\
\hline Natural Gas & 1. & Titas & 140.06 & 111.47 & 49.61 \\
& 2. & Bakhrabad & 1.90 & 11.94 & 18.73 \\
& 3. & Karnafuli & 62.86 & 43.38 & 43.56 \\
& 4. & Jalalabad & 5.96 & 8.70 & 9.09
\end{tabular}

\footnotetext{
12 This is the portion of income derived from production by incorporated enterprises that is earned by the capital factor.
} 


\begin{tabular}{lllrrr} 
& 5. & GTCL & 23.14 & 45.20 & -5.26 \\
& 6. & BGFCL & 13.39 & 14.09 & 27.06 \\
& 7. & SGFL & 41.22 & 55.67 & 34.45 \\
& 8. & PGCL & 2.33 & 4.41 & 2.47 \\
& 9. & BAPEX & 3.82 & 6.98 & 0.34 \\
& 10. & RPGCL & 6.35 & 8.10 & -12.25 \\
& & Natural Gas & $\mathbf{3 0 1 . 0 5}$ & $\mathbf{3 0 9 . 9 4}$ & $\mathbf{1 7 5 . 7 5}$ \\
Coal & 1. & Barapukuria & 4.19 & 42.02 & 29.42 \\
\hline
\end{tabular}

Source: Calculation based on Petrobangla and BBS (2017) data.

Based on the SEEA Central Framework (2014), we assume that the future resource rent is a function of the resource rent of the most recent years. Thus, expected resource rents were derived from the moving average of stocks of the last three years. To control the unusual number for resource rents, we excluded the resource rent for 2013-14 in calculating the moving average as per the Central Framework. In addition, the extractions of stocks were also projected based on the moving average of the last three consecutive years.

The next step is to set the discount rates for each of the resources (Tables 5 and 6). A higher discount rate indicates a lower time preference or reduced priority of future consumption. In the SEEA, a discount rate is perceived as a rate of interest which is used to adjust the value of a stream of future flows of revenue or income so that the value of future flows can be compared with that of the current flows. Generally, social discount rates are lower than market-based discount rates while the lower rates will place a higher relative importance on the income earned by future generations (SEEA, 2014). Dasgupta (2008) expresses the social discount rate as the society's deliberation over a 'consumption swap'between today and tomorrow. According to Ahmed (2000), from an empirical perspective, the discount rate for Bangladesh is 15 percent. In comparison, the social discount rates are 3 and 10 percent for the US (Nordhaus, 2000), and 4 percent for the Netherlands for oil and gas (Veldhuizen et al., 2009). Following consideration of various studies, Rubio (2005) suggests 3, 6 and 15 percent social discount rates in valuing minerals.

Table 5: Monetary Balance of Natural Gas (million USD)

\begin{tabular}{rlcrrrrr}
\hline \hline S1 & Resource Stock & $2011-12$ & $2012-13$ & $2013-14$ & $2014-15$ & $2015-16$ & $2016-17$ \\
\hline $\mathbf{1}$ & Opening balance & $\mathbf{3 , 4 4 2}$ & $\mathbf{4 , 1 2 8}$ & $\mathbf{4 , 4 9 5}$ & $\mathbf{4 , 6 3 8}$ & $\mathbf{4 , 8 0 1}$ & $\mathbf{4 , 9 8 6}$ \\
2 & $\begin{array}{l}\text { Additions to stock } \\
\text { Discoveries }\end{array}$ & 11 & 62 & 14 & & & \\
& $\begin{array}{l}\text { Upward reappraisals } \\
\text { Reclassifications }\end{array}$ & 68 & & & & \\
& $\begin{array}{l}\text { Total additions to stock } \\
\text { Reductions in stock }\end{array}$ & 80 & 62 & 14 & 17 & 91 \\
\end{tabular}




\begin{tabular}{|c|c|c|c|c|c|c|c|}
\hline & Extractions (Gas) & 239 & 307 & 339 & 327 & 363 & 349 \\
\hline & \multicolumn{7}{|c|}{ Extractions (others petroleum) } \\
\hline & \multicolumn{7}{|c|}{ Catastrophic losses } \\
\hline & \multicolumn{7}{|l|}{ Downward reappraisals } \\
\hline & \multicolumn{7}{|l|}{ Reclassifications } \\
\hline & Total reductions in stock & 239 & 307 & 339 & 327 & 363 & 349 \\
\hline 4 & Revaluations & 845 & 612 & 468 & 473 & 457 & 365 \\
\hline \multirow[t]{2}{*}{5} & Closing balance & 4,128 & 4,495 & 4,638 & 4,801 & 4,986 & 5,002 \\
\hline & SNA & 239 & 307 & 339 & 327 & 363 & 349 \\
\hline
\end{tabular}

"In the case of natural gas, other extractions from the same field include other petroleum products such as petroleum and condensate. Calculation was done at the 3.5 percent discount rate.

Source: Calculation based on Petrobangla and BBS (2017) data.

The SEEA Central Framework (2014) suggests using the social discount rate for the valuation of non-renewable resources as it reflects the time and risk preferences of the entire society. In Bangladesh, the government owns the sub-soil minerals which are under consideration in the present study and is expected to make decisions about extraction on behalf of the society. However, we use different discount rates to analyze the sensitivity of the results (Figure 4). Furthermore, we make two assumptions in preparing the monetary balance sheet, that proven and probable reserves are always extracted first and that the social discount rate is a minimum 3.5 percent.

\section{Figure 4: Closing Stock of Natural Gas (million USD) at Different Discount Rates}

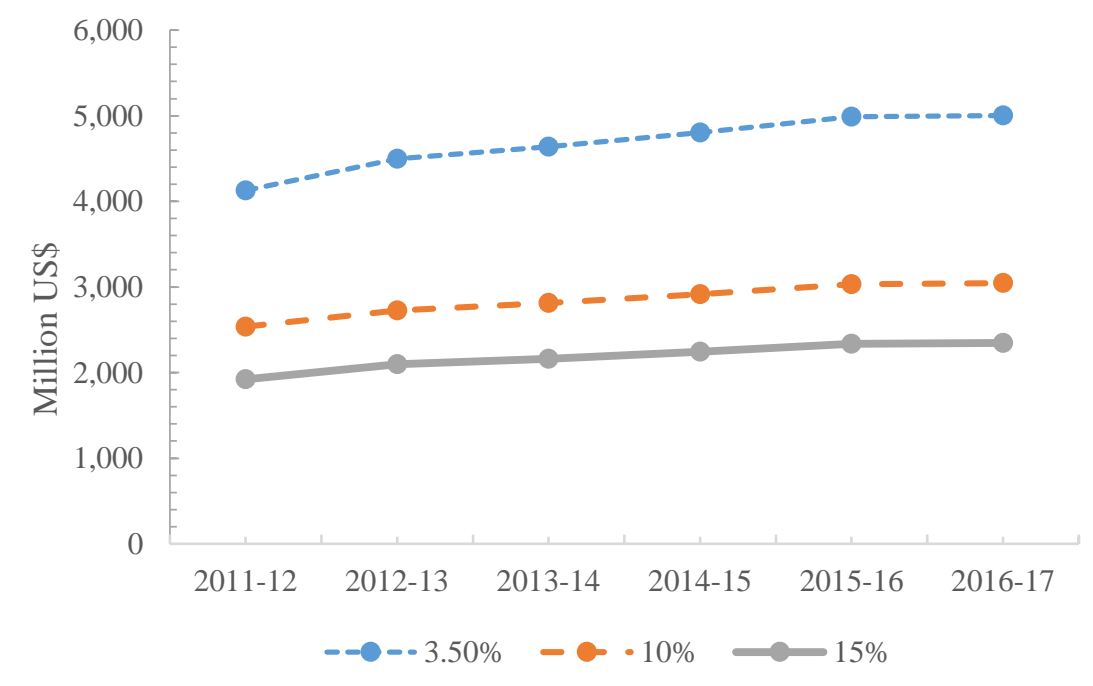

Source: Calculation based on Petrobangla and BBS (2017) data.

The monetary balance shows that there is a jump in the value of the natural gas reserve in 201213, which was because of new discoveries and reappraisal. However, although it remains the same 
in the local currency unit, the monetary value of the opening stock of the current fiscal year is different from the closing stock of the last fiscal year because of changes in the annual average exchange rate. Besides, the stock value is highly sensitive to the discount rate, which indicates a higher preference for present consumption that will, in turn, significantly reduce the present and future value of the stock.

Contrary to the monetary balance of natural gas, the reserve value of coal varies significantly in response to changes in the discount rate (Figure 5). At the 3.5 percent discount rate, the stock value of coal rises as high as USD 81 billion in 2013-14 while it comes down to only USD 22 billion (or just one-fourth) in the same year at the 10 percent discount rate. At the 15 percent discount rate, it goes down even further to USD 9 billion. On the other hand, the stock value of natural gas comes down to two-thirds of its previous value in response to changes in the discount rate from 3.5 to 10 percent. It shows that the time preference is highly sensitive to the reserve value of coal compared to that of natural gas.

Table 6: Monetary Balance of Coal (million USD)

\begin{tabular}{|c|c|c|c|c|c|c|c|}
\hline $\mathrm{Sl}$ & Resource Stock & 2011-12 & 2012-13 & 2013-14 & $2014-15$ & 2015-16 & 2016-17 \\
\hline 1 & Opening stock & 53,150 & 69,195 & 75,352 & 80,838 & 89,493 & 99,817 \\
\hline \multirow[t]{5}{*}{2} & Additions to stock & & & & & & \\
\hline & Discoveries & & & & & & \\
\hline & Upward reappraisals & & & & & & \\
\hline & Reclassifications & & & & & & \\
\hline & Total additions to stock & & & & & & \\
\hline \multirow[t]{6}{*}{3} & Reductions in stock & & & & & & \\
\hline & Extractions & 12 & 26 & 42 & 18 & 29 & 29 \\
\hline & Catastrophic losses & & & & & & \\
\hline & Downward reappraisals & & & & & & \\
\hline & Reclassifications & & & & & & \\
\hline & Total reductions in stock & 12 & 26 & 42 & 18 & 29 & 29 \\
\hline 4 & Revaluations & 16,033 & 6,131 & 5,444 & 8,673 & 10,353 & 5,892 \\
\hline \multirow[t]{2}{*}{5} & Closing stock & 69,195 & 75,352 & 80,838 & 89,493 & 99,817 & 105,680 \\
\hline & SNA* ${ }^{*}$ & 140 & 170 & 178 & 188 & 208 & 206 \\
\hline
\end{tabular}

" The monetary balance of coal in the SEEA is based on change of stock through extraction and revaluation of the entire stock of coal in all mines. However, in the SNA, the value of domestic product of coal is only based on market value of output extracted from the only domestic coal mine.

Note: Calculation was done at the 3.5 percent discount rate. Source: Calculation based on Petrobangla and BBS (2017) data.

In summary, the results reveal that the stock value of coal is about eight times higher than that of natural gas even though the latter is regarded as the most important subsoil mineral of the top mineral resources in Bangladesh. This implies that coal can add significant value to the GDP of Bangladesh for many years to come. However, measures must be taken to generate power and 
energy from this mineral through environment-friendly technologies such as clean coal to minimize carbon emission and heating.

\section{Figure 5: Closing Stock of Coal (million USD) at Different Discount Rates}

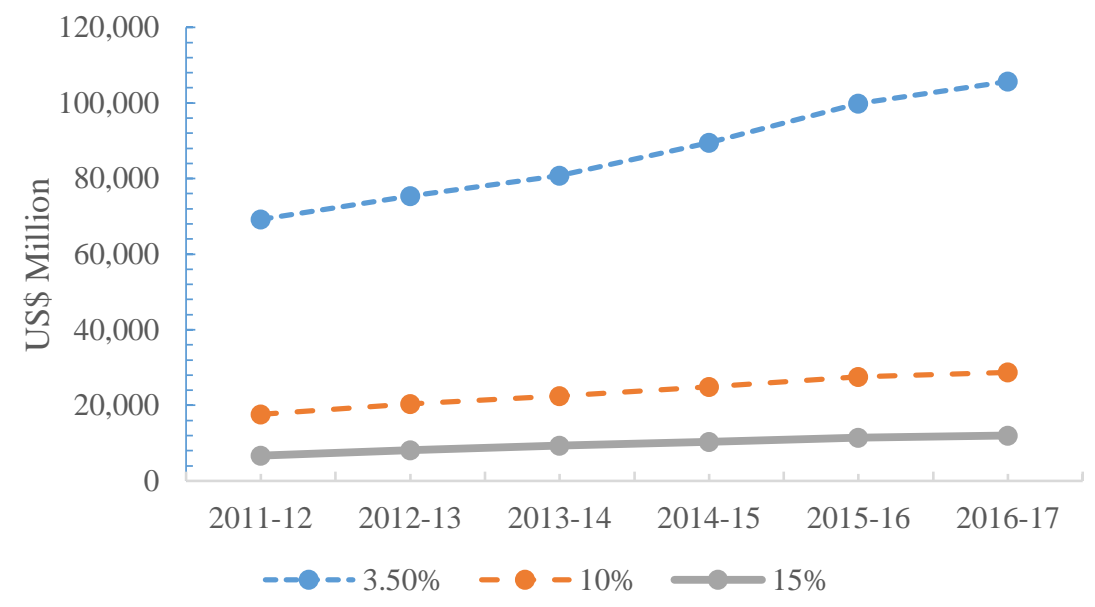

Source: Calculation based on Petrobangla and BBS (2017) data.

\section{Issues for National Accounting}

The valuation of selected sub-soil minerals offers some powerful insights to conventional national income accounting. The resources are extracted or depleted to earn income during the period of their respective stocks and re-evaluated to determine the increasing or decreasing value of the stock. Theoretically, changes in the value of the stock through depletion and re-evaluation at the beginning and end of the period to capture the flow or income. There might be unexpected events like depreciations or catastrophic losses, which may lead to a depletion of the physical stock without earning an income. These are also deducted from the physical and monetary balance sheets. Conversely, the traditional SNA only considers the income or return of resources in a particular year. Thus, the income (flow) can be calculated from the stock in two different periods, which would be different in the SEEA compared to the traditional SNA. Even though the SEEA Central Framework (United Nations et al., 2014) does not indicate how national income can be 
worked out from the value of stock, the GDP coming from a resource can be expressed as the difference between the value of opening and closing stock. The value of opening stock is the value of closing tock of the last accounting year, which is added to by new discoveries, upward reappraisals and reclassifications, and flow of the resource to an economy after extraction to provide the value of the new closing stock. Moreover, revaluation of the existing stock because of price change also influences the value of new closing stock of natural gas and coal of the next accounting year. New discoveries in a specific accounting year are not extracted immediately. Rather, they are extracted and reappraised over future years that added gradually in subsequent GDP.

Table 7: Contribution of Natural Gas and Coal to GDP at Current Prices (Million US\$)

\begin{tabular}{|c|c|c|c|c|}
\hline & \multicolumn{2}{|c|}{ Natural gas \& crude petroleum } & \multicolumn{2}{|c|}{ Other mining \& quarrying } \\
\hline & SNA & SEEA & SNA & SEEA \\
\hline $2011-12$ & 900 & 1,164 & 1,135 & 16,045 \\
\hline 2012-13 & 1,023 & 981 & 1,480 & 6,157 \\
\hline 2013-14 & 1,051 & 821 & 1,665 & 5,486 \\
\hline 2014-15 & 1,181 & 817 & 1,888 & 8,691 \\
\hline $2015-16$ & 1,366 & 911 & 2,280 & 10,382 \\
\hline 2016-17 & 1,489 & 714 & 2,745 & 5,921 \\
\hline
\end{tabular}

Notes: (1) For the SEEA only coal is included in other mining \& quarrying while coal and hard rock are included in SNA. Kabir (2017) shows that hard rock adds insignificant value calculated in the SEEA. Therefore, hard rock is excluded from the current calculation.

(2) The SEEA is based on UN System of National Accounts while the SNA is followed by BBS national accounting statistics.

Thus, the GDP coming from the subsoil minerals can be expressed as the sum of extraction and revaluations in response to price changes in an accounting year that give the difference between the value of opening and closing stocks (Table 7). The analysis reveals that the total GDP from subsoil minerals turns out to be much higher than that of the traditional SNA even though the value of natural gas in the valuation method of the SEEA is lower than that of the SNA. It is mainly because the valuation in the SEEA is based on deduction of all user costs of produced capital, subsidies and factors in the discount rate. However, since final value addition in the SNA is based on the constant market price of extracted gas (including condensates as bi-product) but does not adjust the discount rate and deduct subsidies or different costs covered by the state-owned Petrobangla, the value added from natural gas and crude petroleum is higher in the SNA than that of the SEEA method. 
The second critical issue overlooked in the calculation of the value of subsoil minerals in the SEEA is due to simplification related to the investment spending on resources for development and protection from catastrophic losses. As mentioned in Section 3, all expenditures including the user cost of capital and cost of extraction to make the resources available for consumption are included in the net income from extraction. Thus, costs of investment and protection of resources are not included explicitly in the valuation although it would be included in investment spending at the government mines and the IOC-operated mines. The unit resource rent would have been lower if such costs were explicitly factored in.

The third issue is related to the services of resources, which have not been transmitted into valuation principles. The three ecosystem services in question are provisioning, regulating and cultural services (SEEA Experimental Ecosystem Accounting, 2014). The extraction of a resource causes income flow (provisioning) but consumption of the resource also leads to carbon emission (regulating) and the eviction of people living in mine areas either for development of the mines or when there are explosions (cultural). But the issue of provisional services is not directly included in the Central Framework in the context of resource valuation although it is covered in the Environmentally Extended Social Accounting Matrix in the satellite account. However, the private and public costs of eviction and resettlement have not been properly covered in the SEEA.

\section{Conclusions and Policy Implications}

This paper attempts to conduct an alternative national accounting for two important natural resources for Bangladesh. To do so, we use the SEEA framework, which outlines the method of preparing physical and monetary balance sheets and we prepare physical and monetary balance sheets for natural gas and coal. We find that the physical stock of natural gas has been diminishing rapidly, which is because of a very high level of use of this resource in many sectors for present consumption. The annual reduction of stock ranged from 6.94 to 7.56 per cent of the monetary value of the stock between 2011-12 and 2016-17 with fluctuations over time. However, in terms of share of physical stock the reduction of stock has been increasing steadily; it was 4.83 per cent of monetary balance in 2011-12 and 7.25 per cent in 2016-17. This implies that the decrease in higher quantity of natural gas from the stock could not be properly represented by the monetary balance because of the present aggressive rate of extraction. Besides, even though the value of the stock of coal is from 15 to 20 times greater than that of natural gas during the same period, the annual reduction of stock was very low, from around 0.023 to 0.056 per cent of the value of stock 
of coal. A very low rate of extraction helped keep the value of stock increasing rapidly, while revaluation of stock between the two closing periods added to coal's significant net value. In addition, the value of stock of both the minerals has been found to be highly sensitive to the choice of discount rate; for a lower discount rate the value of stock is higher and vice versa.

We make two other observations in this regard. Among other aspects needing attention, one of the most important is the availability of subsoil minerals that are facing rapid depletion that may result in eventual disappearance in a decade or so. Therefore, setting a low social discount rate is imperative to understand the importance of giving priority to preserving exhaustible natural resources for future generations. The second aspect is related to the greater value of future consumption. In the context of the government monopoly, the Energy Regulatory Commission (ERC) of Bangladesh decides on the energy tariff, including that for natural gas, but for political reasons the gas tariff has not experienced a significant increase over the last half a decade. Indeed, the real price of natural gas has gone down. Thus, greater emphasis on non-renewable natural resources in future consumption would contribute to a higher added value to the national income. It calls for policy attention to reform the national accounting to better reflect the future value of these resources.

Sub-soil minerals like natural gas and coal are widely used as energy sources in Bangladesh with the economy crucially dependent on them for economic activities. Moreover, attempts to attain higher growth are expected to result in greater energy use and are bound to have the significant but expected consequence of rapid depletion of the stock or reserve due to overextraction. Achievement of optimal rates of extraction thus requires the lowering of social discount rates to ensure greater consumption opportunities for future generations and sustainable development.

The SEEA is difficult to operationalize in a developing country such as Bangladesh where the national statistical agency is not yet ready for environmental accounting in all sectors of the economy. Hence, such accounting in a critical sub-sector or product that has important implications on other sectors of the economy might be a place to start. The findings of this paper may be useful to the Bangladesh Bureau of Statistics (BBS) as it develops its capacity to use the SEEA. In addition, the result of the SEEA should be presented in the estimated figures of national income vis-à-vis the value of output under the traditional SNA to understand the contribution of subsoil minerals in green national accounting. It can be done through a satellite account of the 
traditional SNA. The sectoral monetary balance would be useful to prepare national supply and to construct an environmentally extended social accounting matrix, and to conduct material footprint analysis to understand sustainable production and consumption in light of the Sustainable Development Goals (SDGs). Finally, studies should be conducted to estimate the total value of natural assets, which may include minerals, water, forestry, and land of the nation by applying the SEEA.

\section{Acknowledgements}

This paper is based on the first author's study titled "Valuation and Emission Accounting of Sub-Soil Minerals: The Case of Natural Gas and Coal in Bangladesh" which received financial support from the South Asian Network for Development and Environmental Economics (SANDEE). The authors are thankful to the sponsors. They would also like to record their appreciation of the technical support and guidance provided by several SANDEE advisors and peers. The authors are particularly grateful to A K Enamul Haque, Priya Shyamsundar, Jeffery Vincent and Pranob Mukhopadhay for their suggestions during the SANDEE Research \& Training Workshop in Colombo in June-July 2015 and in Kathmandu in December 2014 and 2015. The authors also benefited from the suggestions of participants of the International Conference on Green Accounting in South Asia at IESC, Bengaluru, in February 2015. They also acknowledge the valuable comments of Muhammad Abdul Mannan (Minister, Ministry of Planning, Government of Bangladesh), Abul Kalam Azad (Director, National Accounting Wing, Bangladesh Bureau of Statistics) and other participants at the National Seminar held at BIISS in Dhaka on 16 March 2016. They also acknowledge with gratitude the research assistance of Robert Shuvro Guda. The authors also acknowledge the comments and suggestions from the anonymous reviewer and of Professor Fleming-Muñoz, editor of this journal, which materially improved the quality and presentation of this article. However, the authors are responsible for any errors that remain. 


\section{References}

Bangladesh Bureau of Statistics. (2017), Statistics Yearbook 2016. Dhaka: Planning Commission.

Cairns, R.D. and G.A. Davis (1998), 'Economic theory and the valuation of mineral reserves', OPEC Energy Review 22(3): 169-183.

Dasgupta, P. (2008), 'Discounting climate change', Journal of Risk and Uncertainty 37(2-3): 141-169.

Dasgupta, P. (2013), Green National Accounts in India: A Framework, Report by an Expert Group Convened by the National Statistical Organization, Ministry of Statistics and Programme Implementation, Government of India, New Delhi.

DESA. n.d. SEEA, Applications and Extensions, Statistics Division, United Nations, New York.

Hamilton, K. (1996), 'Pollution and pollution abatement in the national accounts', Review of Income and Wealth 42(1): 13-33.

Howarth, R. B. and S. Farber (2002), 'Accounting for the value of ecosystem services', Ecological Economics 41: 421-429.

Harrison, A. (1989), Introducing Natural Capital into the SNA, in Y. A. Ahmad, S. El Serafy and E. Lutz (eds.), Environmental Accounting for Sustainable Development, UNEP-World Bank Symposium, Washington D.C., World Bank, 19-25.

Hartwick, J. M. (2011), 'Green national income and green national product', Annual Review of Resource Economics 3(1): 21-35.

Hartwick, J. M. (1990), 'Natural resources, national accounting and economic depreciation', Journal of Public Economics 43: 291-304.

Heal, G. and B. Kriström (2005), 'National income and the environment', in K. Mäler and J.R. Vincent (eds.), Handbook of Environmental Economics, vol. 3, Amsterdam: Elsevier, 1148-1217.

Kabir, M. (2017), Valuation of Subsoil Minerals: Application of SEEA for Bangladesh, Working Paper no. 124-17, Kathmandu: SANDEE.

Lawn, P. A. (2003), 'A theoretical foundation to support the Index of Sustainable Economic Welfare (ISEW), Genuine Progress Indicator (GPI), and other related indexes', Ecological Economics 44: 105118.

Mäler, K-G. (1991), 'National accounts and environmental resources', Environmental and Resource Economics 1: 1-15.

Nordhaus, W. D. (2000), 'Accounting for subsoil mineral resources', Survey of Current Business February 2000: 24-50.

Pedersen, O. G. and I. Mulalic (2003), Subsoil Asset Accounting - The Path Forward', Discussion Paper Prepared for the London Group Meeting, 5-7 November 2003, Available at: https://unstats.un.org/unsd/envaccounting/londongroup/meeting8/subsoil asset accounting the path forward.pdf. [Accessed on 27 October 2014]

Petrobangla (2018a), Monitoring and Evaluation Report, July 2018, Dhaka: Petrobangla.

Petrobangla (2018b), Annual Report 2017, Dhaka: Petrobangla.

Rahman, A. (1997), Mineral Resources of Bangladesh and their History, Arambagh, Dhaka: Haq Printers. 
Rubio, M. M. (2005), 'Value and depreciation of mineral resources over the very long run: An empirical contrast of different methods', Economics Working Papers 867, Department of Economics and Business, Universitat Pompeu Fabra, Italy.

United Nations, European Commission, International Monetary Fund, Organisation for Economic Cooperation and Development, and World Bank. (2009), System of National Accounts 2008, United Nations, New York.

United Nations, European Commission, Food and Agriculture Organization, International Monetary Fund, Organisation for Economic Co-operation, and World Bank (2014a), System of EnvironmentalEconomic Accounting: Central Framework, United Nations, New York.

United Nations, European Commission, Organisation for Economic Co-operation, and World Bank (2014b), System of Environmental-Economic Accounting 2012: Experimental Ecosystem Accounting, United Nations, New York.

United Nations Organization (1993), 'Integrated environmental and economic accounting' (Interim version), in Handbook of National Accounting, Series $F$, No. 61, Department of Economic and Social Development, Statistical Division, New York.

Veldhuizen, E., C. Graveland, D. van den Bergen, and S. Schenau (2009), Valuation of Oil and Gas Reserves in the Netherlands - 1990-2005, Statistics Netherlands, The Hague.

Weitzman, M. L. (1976), 'On the welfare significance of national product in a dynamic economy', Quarterly Journal of Economics 90(1): 156-162. 


\section{Appendix}

Map 1: Mineral Resources in Bangladesh (Except Gas and Oil)

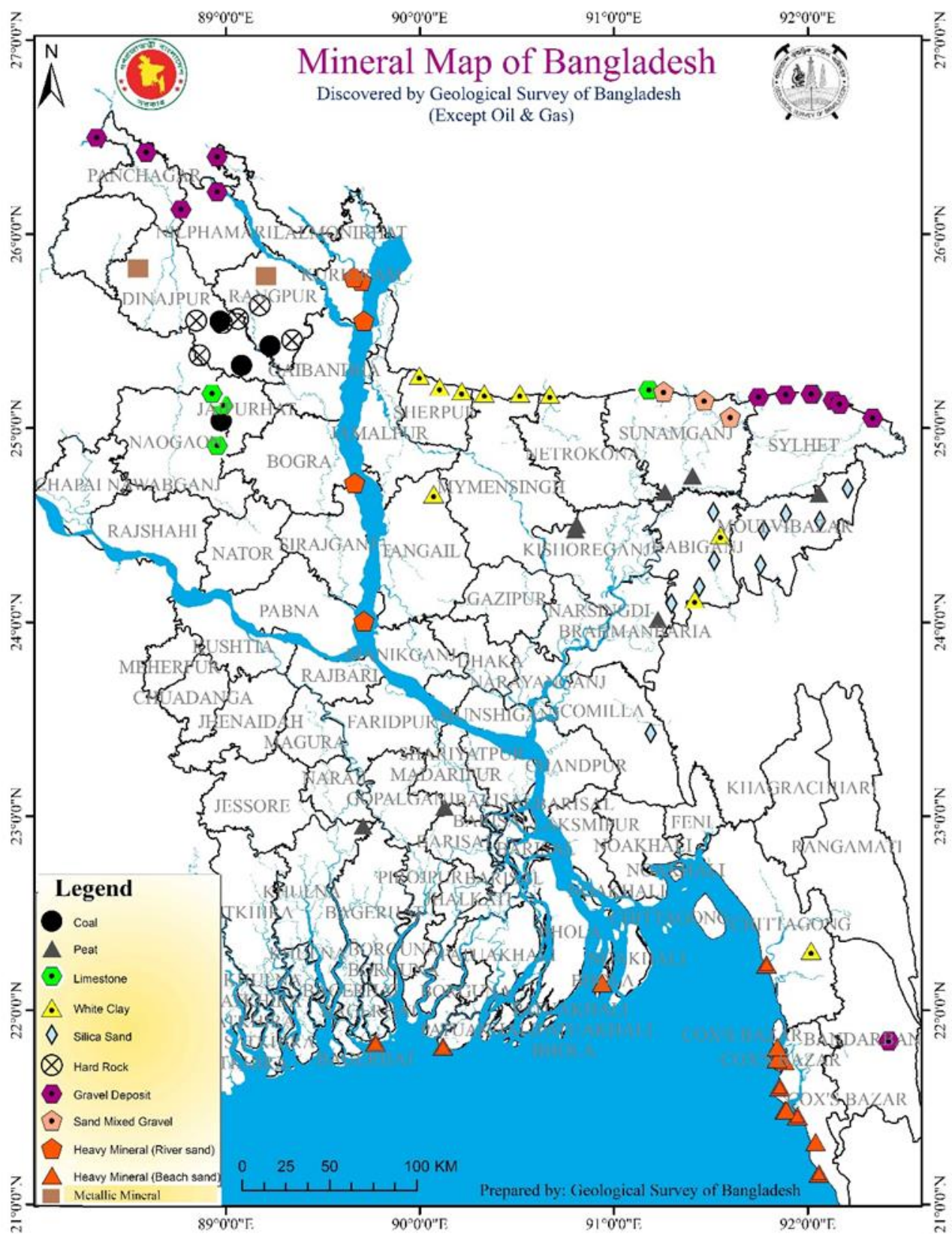

Source: Geological Survey of Bangladesh, available at

http://www.gsb.gov.bd/site/view/commondoc/Mineral\%20Resources\%20Map/, accessed on 4 March 2019. 
Map 2: Bangladesh Natural Gas Block Map, 2017

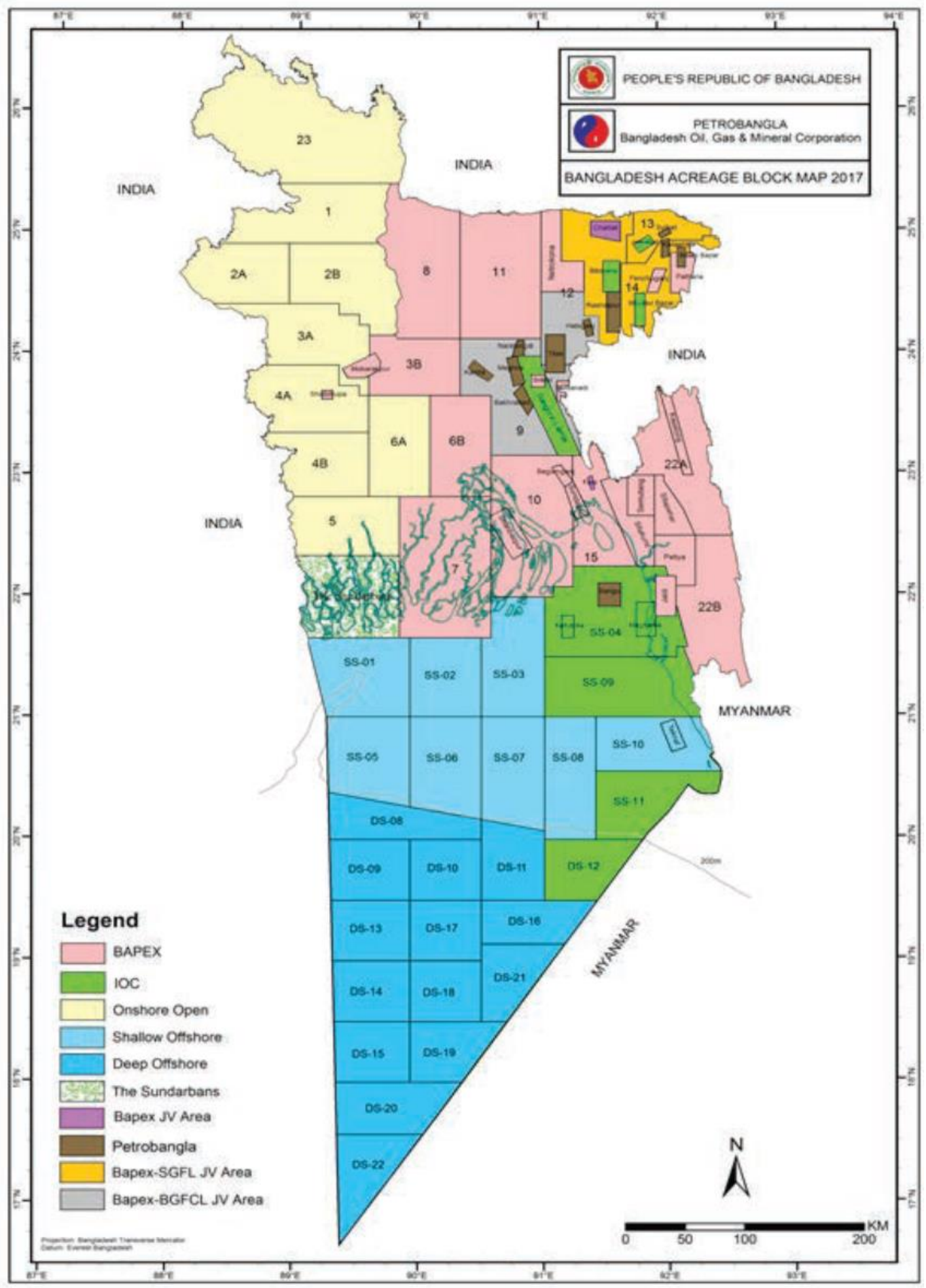

Source: Petrobangla (2018), Annual Report 2017, Dhaka, p.38. 